Article

\title{
Farming Influence on Physical-Mechanical Properties and Microstructural Characteristics of Backfilled Loess Farmland in Yan'an, China
}

\author{
Lina Ma ${ }^{1,2,3}$, Shengwen Qi ${ }^{1,2,3, *}$, Bowen Zheng ${ }^{1,2,3}$, Songfeng Guo ${ }^{1,2,3, *}$, Qiangbing Huang ${ }^{4}$ \\ and Xinbao $\mathrm{Yu}^{5}$ \\ 1 Key Laboratory of Shale Gas and Geoengineering, Institute of Geology and Geophysics, Chinese Academy \\ of Sciences, Beituchengxilu 19, Chaoyang District, Beijing 100029, China; malina@mail.iggcas.ac.cn (L.M.); \\ zhengbowen@mail.iggcas.ac.cn (B.Z.) \\ 2 College of Earth and Planetary Sciences, University of Chinese Academy of Sciences, Yuquanlu 19, \\ Shijingshan District, Beijing 100049, China \\ 3 Innovation Academy for Earth Science, Chinese Academy of Sciences, Beituchengxilu 19, Chaoyang District, \\ Beijing 100029, China \\ 4 Department of Geological Engineering, Chang'an University, Xi'an 710054, China; dcdgx24@chd.edu.cn \\ 5 Department of Civil Engineering, University of Texas at Arlington, 416 Yates St., Arlington, TX 76019, USA; \\ Xinbao@uta.edu \\ * Correspondence: qishengwen@mail.iggcas.ac.cn (S.Q.); guosongfeng@mail.iggcas.ac.cn (S.G.); \\ Tel.: +86-010-82998055 (S.Q.); +86-13439078159 (S.G.)
}

Received: 27 May 2020; Accepted: 30 June 2020; Published: 8 July 2020

\begin{abstract}
A gigantic project named Gully Land Consolidation (GLC) was launched in the hill-gully region of the Chinese Loess Plateau in 2011 to cope with land degradation and create new farmlands for cultivation. However, as a particular kind of remolded loess, the newly created and backfilled farmland may bring new engineering and environmental problems because the soil structure was disturbed and destroyed. In this study, current situations and characteristics of GLC are introduced. Test results show that physical-mechanical properties and microstructural characteristics of backfilled loess of one-year and five-year farmland are significantly affected by the Gully Land Consolidation project. Compared to natural loess, the moisture content, density, and internal friction angle of backfilled loess increase. On the contrary, the porosity, plasticity index, particle size index, and cohesion index decrease. Through SEM tests, it is observed that the particles of backfilled loess are rounded, with large pores filled with crushed fine particles, which results in skeleton strength weakness among particles and pores. The pore size distribution (PSD) of the four types of loess $\left(\mathrm{Q}_{3}\right.$ loess, $\mathrm{Q}_{2}$ loess, one-year farmland, and five-year farmland) was measured using mercury intrusion porosimetry (MIP) tests, showing that the pore size of $Q_{3}$ loess is mainly mesopores $4000-20,000 \mathrm{~nm}$ in size, accounting for $67.5 \%$. The $\mathrm{Q}_{2}$, five-year, and one-year farmland loess have mainly small pores $100-4000 \mathrm{~nm}$ in size, accounting for $52.5 \%, 51.7 \%$, and $71.7 \%$, respectively. The microscopic analysis shows that backfill action degrades the macropores and mesopores into small pores and micropores, leading to weak connection strength among soil particles, which further affects the physical-mechanical properties of loess. The disturbance of backfilled loess leads to an obvious decrease in cohesion and a slight increase in internal friction compared to natural loess. The farming effect becomes prominent with increased backfill time, while the loess soil moisture content increases gradually. Both the cohesion and internal friction of the backfilled loess soil decrease to different degrees. This study is helpful to investigate sustainable land use in the Chinese Loess Plateau and similar areas.
\end{abstract}

Keywords: Gully Land Consolidation; backfilled loess; physical-mechanical property; microstructural characteristic; pore size distribution 


\section{Introduction}

The Chinese Loess Plateau (CLP) covers an area of $640,000 \mathrm{~km}^{2}$ in the upper and middle reaches of the Yellow River. It also has multiple crisscrossing hills and gullies with fractured geological structures [1]. Meanwhile, the semiarid climate, with only $464.1 \mathrm{~mm}$ of average annual precipitation, contributes to the fragility of the ecosystem in the CLP [2]. Owing to aridity, sparse vegetation, and concentrated rainstorms, the CLP is facing serious problems of soil erosion and water loss, becoming the most vulnerable ecological environment in China [3-5].

Since 1949, the ecological management of the CLP has gone through several important stages, such as "slope management," "integration management of gully and slope," "small watershed management," and the "Grain for Green (GFG) project," which increased vegetation coverage and improved ecological quality [6,7]. In particular, since the Chinese government implemented the GFG project in 1999 to convert farmland to forests, shrubland, and grassland, the vegetation coverage rate of the CLP increased significantly, from $31.6 \%$ in 1999 to about $65 \%$ in 2017 [8], thereby reducing soil erosion and water loss to a certain extent $[9,10]$. Most notably, the land consolidation measures dramatically transformed the ecology and landscape of the CLP, turning it from yellow to green [2,11]. However, in recent years, Chinese scientists and government officials have noticed problems: There have been significant reductions in arable land induced by the large-scale implementation of the GFP on the Loess Plateau. Especially in Yan'an, the total area of arable land has reduced by more than half, creating an urgent need for new farmland and a shortage in grain production, which are the main obstacles in sustainable agricultural development [12,13].

On the other hand, Yan'an city has 44,000 gullies that are $500 \mathrm{~m}$ or more in length and 20,900 gullies that are $1 \mathrm{~km}$ or more in length. These numerous gullies have a land creation capacity in Yan'an of about 1.5 million acres [11]. To offset the loss of cropland and cope with land degradation, Shaanxi Province, which has $13 \%$ of the area of the CLP, launched a megaproject called Gully Land Consolidation (GLC) in 2011 [2,14-16], aimed at creating $26.67 \times 10^{4}$ ha of farmland in creek valleys from 2011 to 2020, where the total investment has reached $¥ 30$ billion [17]. The GLC project was officially listed as a major national land improvement project in 2013 [18]. Yan'an City created $3.33 \times 104$ ha of farmland from 2013 to 2017 [19]. The GLC project has become an important measure in increasing areas of cultivated land and to expand land resources. Meanwhile, it also effectively reduces the loss of soil and water in trenches, which can largely alleviate the problem of land shortage and support agricultural modernization [20].

As new comprehensive management, the main approaches of GLC include reshaping valleys by incising foot slopes, filling gullies and stream channels, constructing or rebuilding drainage canals, dams, and reservoirs, and creating flat farmlands $[2,11,19]$. The backfilled loess from farmland in the GLC is a special type of remolded soil. After field investigations, although layered excavation and mechanical compaction were used in the construction process, these operations and management still lack unified and standard guides. Some essential indicators that affect the arability of farmland soils, such as the layered thickness of backfilled soils, tamping methods, and soil compaction, were not adequately demonstrated and implemented. This results in uneven compaction of newly constructed farmland and vast differences of microstructure among backfilled loess. The microstructure is the fundamental structural unit of soil, including grain morphology, grain contact patterns, pore characteristics, and pore size distribution (PSD) [21-24]. Different types of loess have significantly different microstructural characteristics, even if the same type also shows distinctly different microstructure under different pressure, moisture content, dry density, and other conditions. Furthermore, the macroscopic and mechanical properties of soils, such as shear behavior, compressibility, collapsibility, and permeability, are controlled by its microstructural characteristics [25-27]. Under the influence of rainfall and irrigation, collapse subsidence is likely to occur, causing some new engineering and environmental problems.

However, there are few studies on the engineering characteristics of backfilled loess in the GLC in China and also around the world. Based on this, this paper selected two gullies of Chunshuyaozi (CSYZ) and Shijiagou (SJG) as study areas, which were typical GLC sites in the "National Soil and 
Water Conservation Demonstration Park of South Gully." Four types of loess samples were collected with minimal disturbance, including natural samples of Middle Pleistocene Lishi loess $\left(\mathrm{Q}_{2}\right)$ and Upper Pleistocene Malan loess $\left(Q_{3}\right)$ from the excavated slope and backfilled samples from two farmlands located in the reshaped CSYZ and SJG gullies. Farmland in the CSYZ gully has been backfilled for five years, and that in the SJG gully for one year. Moreover, a series of routine soil tests were performed on the four types of loess samples, including basic physical property tests, direct shear tests, and compression tests. Meanwhile, this study also investigated the microstructural characteristics of the loess by conducting scanning electron microscope (SEM) and mercury intrusion porosimetry (MIP) tests. By comparing the physical-mechanical properties and microstructural characteristics of four types of loess samples, this paper shows the evolution of backfilled loess and provides a basis for sustainable land use in the CLP.

\section{Materials and Methods}

\subsection{Study Site}

Chunshuyaozi (CSYZ) gully is located in Chunshuyaozi village, Louping town, Ansai district, Yan'an city, Shaanxi Province, and is where the GLC project was implemented in 2013. After the farmland construction was completed in one year, the farmland was immediately planted. So far, it has been five years since CSYZ farmland was backfilled. Figure $1 \mathrm{a}, \mathrm{b}$ shows satellite images of CSYZ before and after the GLC, taken on 21 July 2010 and 12 March 2019, respectively. Through comparison, it was found that the morphology of these slopes and trenches changed significantly after excavation and backfill.
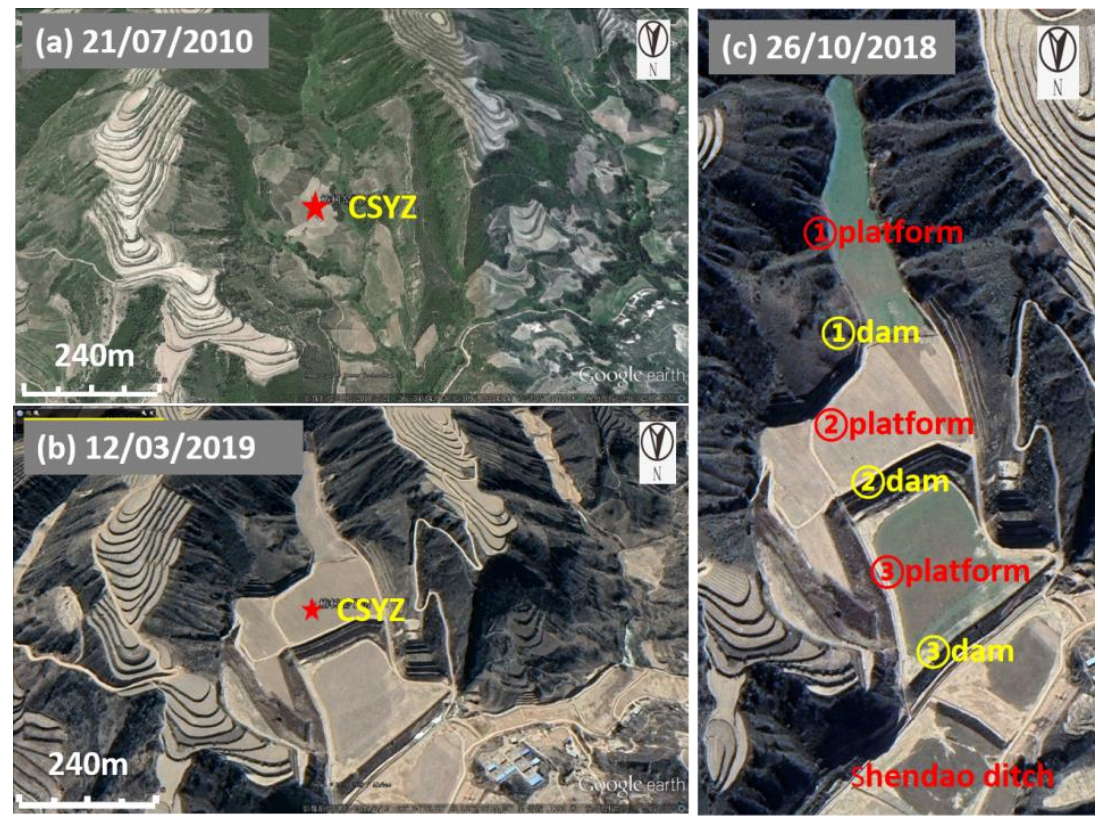

Figure 1. Satellite images of Chunshuyaozi (CSYZ) gully (a) before and (b) after the Gully Land Consolidation (GLC) project. (c) Morphology of CSYZ gully.

The main direction of the CSYZ gully is north-south, with the head on the south side (Figure 1c). The farmlands are composed of three platforms and three sedimentary dams. The first-level platform is elongated and irregular, located at the south of the gully, and is $40 \mathrm{~m}$ wide in the south and $100 \mathrm{~m}$ wide in the north. A field survey showed that the major plant was alfalfa. Close to the north side of the first-level platform is the first-level dam, which is about $2.5 \mathrm{~m}$ high and nearly $50 \mathrm{~m}$ wide. The second-level platform is irregular and polygonal, with a length of $300 \mathrm{~m}$ in the east-west direction and about $130 \mathrm{~m}$ in the north-south direction. The main crop in this platform is black wolfberry. 
The secondary dam on the north side of the secondary platform has a height of about $15 \mathrm{~m}$ and a length of about $230 \mathrm{~m}$ in the east-west direction and consists of four steps. The third-level platform is an irregular square and resembles a dustpan. It is about $200 \mathrm{~m}$ long from north to south and about $170 \mathrm{~m}$ from east to west, and is mainly planted with canola. The gully mouth area is the third dam with a length of about $300 \mathrm{~m}$ from east to west and a height of about $5 \mathrm{~m}$. Intersecting with the CSYZ gully is the Shendao gully in a nearly NW direction.

The Chang'an University team revealed the main stratigraphy of the CSYZ gully from new to old: $Q_{3}$ loess, $Q_{2}$ loess, Hipparion red soil of the Pliocene Series, and underlying sandy mudstone of Zaoyuan section, Yan'an Formation in the lower Jurassic $\left(\mathrm{J}_{1}\right)$. The thickness of $\mathrm{Q}_{3}$ loess was mainly between 15 and $25 \mathrm{~m}$, and some parts can reach $30 \mathrm{~m}$. The thickness of Q2 loess ranged from 30 to $60 \mathrm{~m}$. Loess in gullies mainly included backfilled loess of $\mathrm{Q}_{3}$ and $\mathrm{Q}_{2}$, between 10 and $25 \mathrm{~m}$ depth. The ground water level of the original slope in this study area was $72 \mathrm{~m}$ deep. The thickness of backfilled farmland was between 12 and $22 \mathrm{~m}$ due to the undulations of the original channel [28].

Shijiagou (SJG) gully, located in the east of South Gully village, Louping township, Ansai district, Yan'an city, Shaanxi Province, began to implement the GLC project in 2019. Figure 2a,b shows satellite images of SJG before and after the GLC, taken on 13 February 2010 and 12 March 2019, respectively. The direction trend of SJG gully is NE $45^{\circ}$, with a length of $600 \mathrm{~m}$. The backfilled farmlands are composed of five platforms and five sedimentary dams. A field survey showed that the major plant in SJG was alfalfa. The SJG gully is just $1.5 \mathrm{~km}$ away from the CSYZ gully in the southeast direction, and thus the strata are similar.
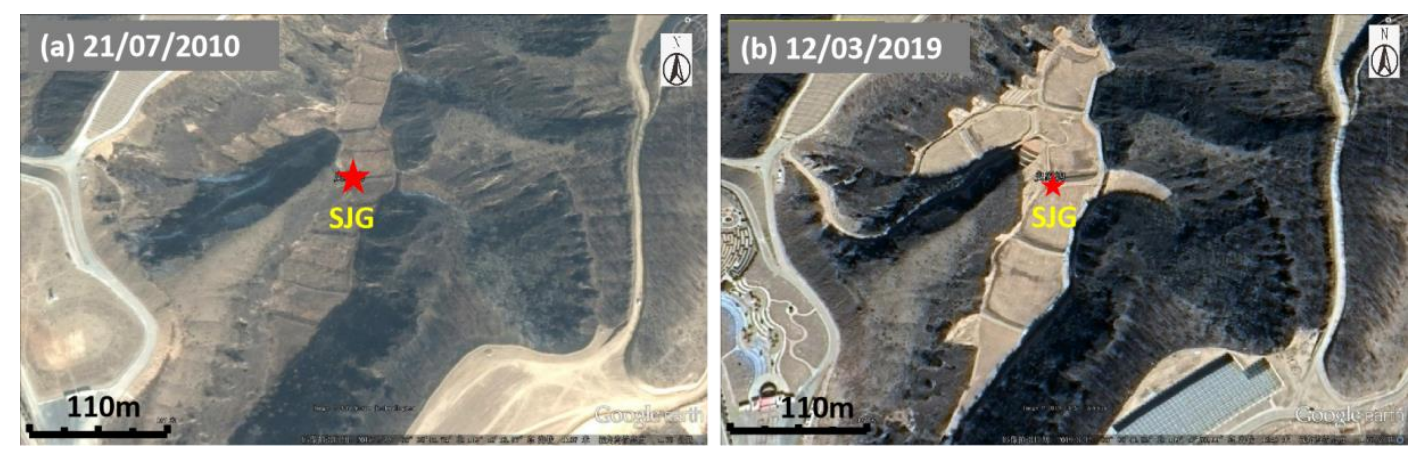

Figure 2. Satellite images of Shijiagou (SJG) gully (a) before and (b) after GLC.

\subsection{Soil Sampling}

Loess soil samples were taken from 14 sampling sites of the excavated slopes and the backfilled farmlands in the study area, eight sites in the CSYZ gully, and six sites in the SJG gully. Two parallel samples were taken from each site. For the CSYZ gully, the sampling site labeled $Q_{3}$ is $Q_{3}$ loess located in the middle-upper part of the southern slope, which is about $15 \mathrm{~m}$ from the crest of the slope in the vertical direction and $1 \mathrm{~m}$ from the slope surface in the horizontal direction. The sampling site labeled $\mathrm{Q}_{2}$ is $\mathrm{Q}_{2}$ loess located in the lower part of the western slope, which is about $55 \mathrm{~m}$ from the crest of the slope in the vertical direction and $1 \mathrm{~m}$ from the slope surface in the horizontal direction. The sampling sites labeled F-C- 1 to F-C- 6 are backfilled loess, and samples were taken from about $0.5 \mathrm{~m}$ depth. Among them, F-C-1 is on the northern side of the second-level farmland, F-C-2 and F-C-3 are on the middle-upper and lower part of the secondary dam, respectively, and F-C-4 to F-C-6 are on the southern side of the three-level platform, from east to west (Figure 3). 


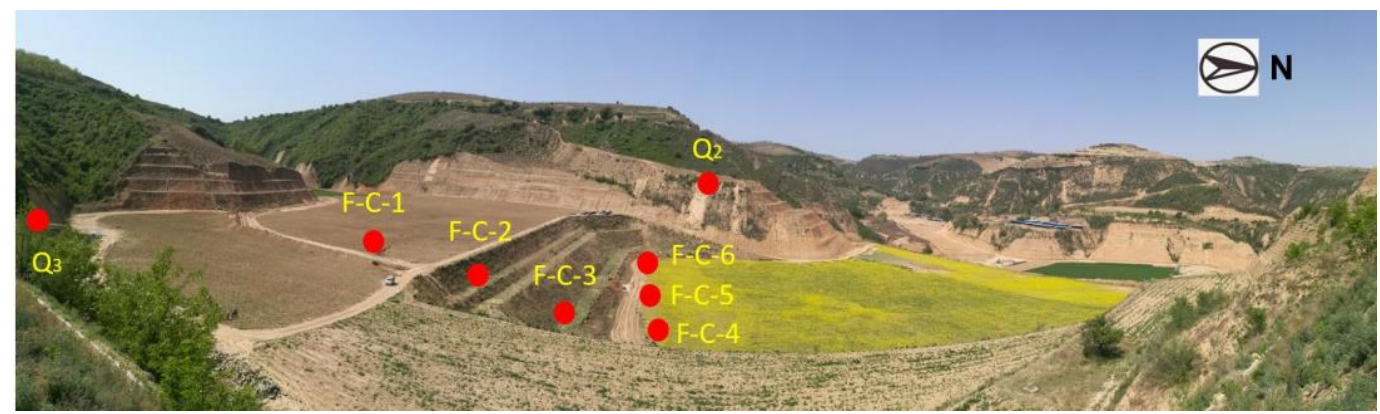

Figure 3. Plan of CSYZ gully and sampling location.

For the SJG gully, sample sites labeled F-S-1, F-S-2, and F-S-3 are located on the west side of the fifth-level platform, respectively, from south to north, and sample sites labeled F-S-4 to F-S-6 are on the south side, from west to east. The sampling depth was about $0.5 \mathrm{~m}$ (Figure 4 ).

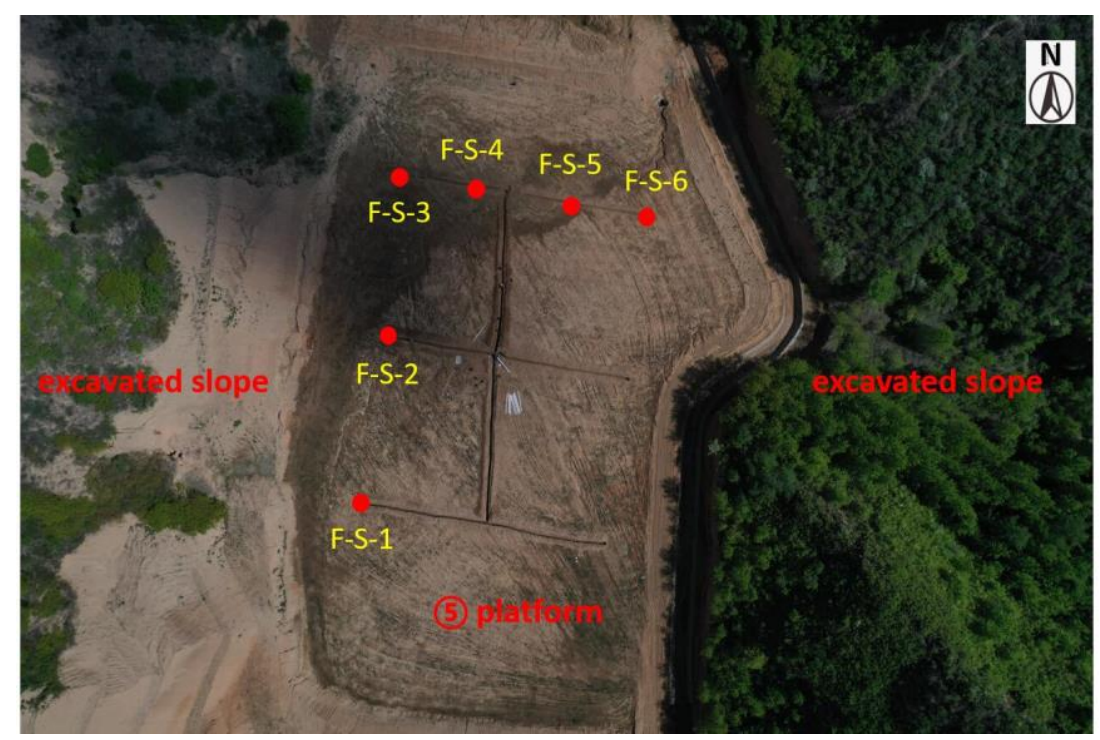

Figure 4. Plan of SJG gully and sampling location.

All soils were sampled by an undisturbed sampling method. Through experience, we found that the advantages of PVC sampling cylinders are that they are sealable, impervious, and lightweight compared to traditional iron cylinders. PVC pipes were cut into short tubes $16 \mathrm{~cm}$ in height and $11 \mathrm{~cm}$ in diameter in advance. Cardboard plates $11 \mathrm{~cm}$ in diameter were made from cardboard boxes to be used as caps for the PVC tubes. The sampling process and method are as follows (Figure 5): First, about the top $0.5 \mathrm{~m}$ surface layer was removed at the sampling site, and the soil was excavated to make an intact soil block about $25 \times 20 \times 20 \mathrm{~cm}$ (Figure 5a,b). A PVC tube was placed on top of the soil block and gently pushed into the block while the surrounding soil was trimmed off (Figure $5 c, d$ ). Then, multiple layers of preservative film were used to completely seal the PVC tube in order to preserve the soil moisture from evaporation loss. Cardboard plates were taped to both ends of the tube to secure the soil sample and prevent disturbance (Figure 5e). The tube was marked with the sample number and placed in a box to be transported to the laboratory. 

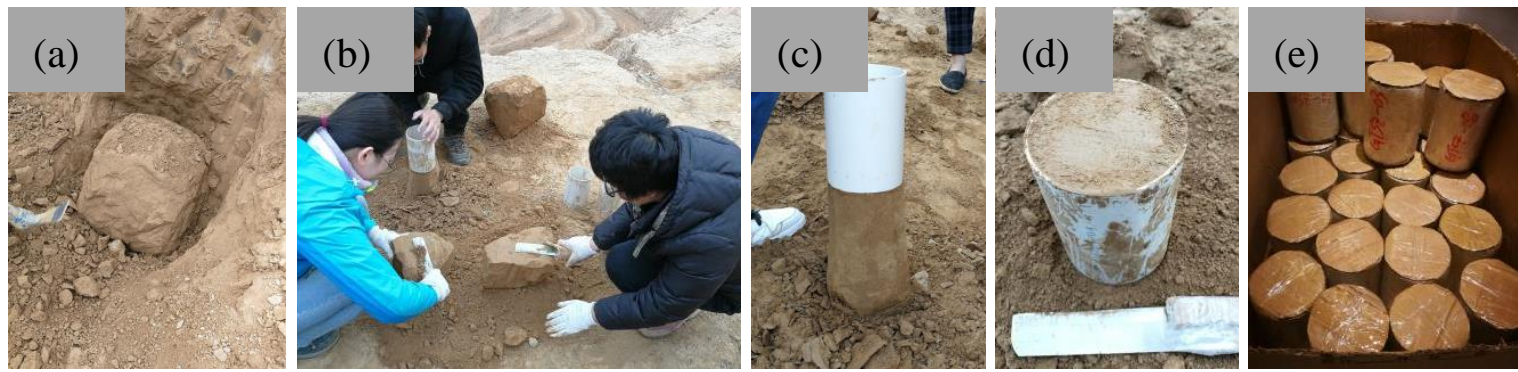

Figure 5. Sampling process: (a) Excavation of soil block from sampling site, (b) cutting to suitable size, (c) pressing the soil sample, (d) sampling by PVC pipe, (e) sealing the soil sample.

\subsection{Experimental Method and Design}

Tests of basic physical properties on 28 soil samples from 14 sampling sites were conducted, including moisture content, density, specific gravity, liquid limit, plastic limit, and particle analysis, and the following properties were obtained through calculation: Dry density, porosity, saturation, plasticity index, and characteristic index of granularity. All test methods were based on the Geotechnical Test Method Standard GB/T 50123-1999 [29]. Specific gravity was tested with the pycnometer method, and the liquid-plastic limit was tested using the liquid-plastic limit combined determination method. The particle analysis tests were performed by a Malvern Mastersizer 3000 laser particle size analyzer. Samples of $\mathrm{Q}_{3}, \mathrm{Q}_{2}, \mathrm{~F}-\mathrm{C}-4$, and F-S-2 were selected for consolidated and undrained direct shear tests. A total of 14 soil samples of natural and backfilled loess were tested for consolidation and compression. The porosity ratios were obtained, and coefficients of compressibility and modulus of compressibility were calculated. According to the regulations of the test standard, each site should have two specimens, and if the difference between the two values is within the error range, the average of the two is taken as the result. According to the tests, properties of natural $Q_{2}$ and $Q_{3}$ loess are relatively stable, and the values of the two specimens are very close. For SEM and MIP tests, samples of F-C-4 and F-S-2 were chosen to represent CSYZ and SJG loess.

A compression experiment is generally used to study the compressibility of soil. The compression tests of all samples were carried out with GZQ-1 pneumatic automatic consolidometer. Coefficient of compressibility $(\alpha)$ and modulus of compressibility ( $E$ s) were respectively calculated by Equations (1) and (2):

$$
\alpha=\frac{e_{1}-e_{2}}{p_{2}-p_{1}},
$$

where $p_{1}$ is the original pressure, defined as $100 \mathrm{kPa}$; $p_{2}$ is the summation pressure, defined as $200 \mathrm{kPa}$; and $e_{1}$ and $e_{2}$ are corresponding void ratios.

$$
E_{s}=\frac{1+e_{1}}{\alpha},
$$

Scanning electron microscopy (SEM) and mercury intrusion porosimetry (MIP) tests are two well-accepted and effective methods of studying the microstructure characteristics of soils. SEM can obtain microscopic images of the soil surface, which are generally used for qualitative analysis of soil structures. MIP is generally used for quantitative analysis of pore characteristics by measuring the size and distribution of micropores in the soil. In this paper, SEM and MIP tests were performed on loess of $\mathrm{Q}_{3}, \mathrm{Q}_{2}, \mathrm{CSYZ}$, and SJG. The micrographs of particle morphology were analyzed by means of SEM, and the pore size distribution characteristics were measured by MIP. The characteristics of micromorphology, soil grain morphology, grain contact patterns, types of porosity, and pore size distribution were comprehensively analyzed, and the evolution process of microstructure characteristics of backfilled farmland loess with increased backfilled time was discussed.

The apparatus used in SEM tests was an FEI Nova Nano SEM field emission scanning electron microscope. The test steps were as follows: (1) The sample was cut into a cuboid with dimensions 
of $2 \mathrm{~cm} \times 1 \mathrm{~cm} \times 1 \mathrm{~cm}$, air-dried in a light-shielded place, then split into two parts by hand along the middle position, and a flat and fresh side was selected as the observation surface. (2) After the sample was evacuated under vacuum pumping, the surfaces were treated with gold spray. Then the sample was fixed on the target plate with conductive tape and transferred to the observation room. (3) The instrument software was opened to find the right position to observe the sample. The focus was adjusted to obtain optimal images with appropriate brightness at selected degrees of magnification. This experiment was observed at four magnifications: $200 \times, 400 \times, 800 \times$, and $1600 \times$. In this paper, representative images of $200 \times$ and $800 \times$ were selected for analysis.

The test principle of MIP is as follows. This method is based on the assumption that the measured pores are cylindrical. As a noninvasive liquid with liquid surface tension, mercury cannot enter pores without pressure. During the mercury intrusion process, the work of moving mercury into the pores is converted to overcome the work done by the surface tension. Hence the Washburn equation for the external pressure and pore radius was deduced [30] as Equation (3):

$$
P=-\frac{2 \gamma \cos \theta}{r}
$$

where $P$ is the applied pressure $(\mathrm{kPa}) ; r$ is the pore radius $(\mathrm{nm}) ; \gamma$ is the surface tension of mercury, $0.485 \mathrm{~N} / \mathrm{m}$; and $\theta$ is the contact angle of the mercury and the surface of the soil grain, $140^{\circ}$. It can be known from the formula that pressure is inversely proportional to pore size. The greater the applied pressure, the smaller the pore radius that mercury can enter. Mercury intrusion starts from large pores, then mesopores, and finally small pores. By the volume of mercury intrusion at a certain pressure, the volume of the corresponding pore sizes can be determined [31]. The instrument used in this test was a Micromeritics Auto Pore IV 9500, which can provide a pressure range of 3-4 $\times 10^{5} \mathrm{kPa}$, with a corresponding pore size range of $3 \mathrm{~nm}-450 \mu \mathrm{m}$, and the accuracy is $1 \mu \mathrm{L}$. The samples were cut into cuboids of $1 \times 1 \times 1 \mathrm{~cm}$ and air-dried in a light-shielded place.

\section{Results}

\subsection{Tests of Basic Physical Properties}

Basic physical test results can be summarized as follows (Table 1). The results (Figure 6a) show that the moisture content of F-C is between $16.5 \%$ and $18.4 \%$, and F-S is between $19.1 \%$ and $24.4 \%$. Compared with natural loess, there is a significant increase in moisture content of backfilled loess. At the same time, the moisture content of F-C is generally lower than that of F-S, and the scope of the former is less than that of the latter. The results of density tests show a similar tendency (Figure $6 \mathrm{~b}$ ). The density of F-C is about $1.77-1.95 \mathrm{~g} / \mathrm{cm}^{3}$, and that of F-S is about $1.82-2.08 \mathrm{~g} / \mathrm{cm}^{3}$. On average, the density of backfilled loess shows a significant increase compared with the natural loess, and the increase in SJG is greater than that in CSYZ. 
Table 1. Basic physical indices of 14 loess groups.

\begin{tabular}{|c|c|c|c|c|c|c|}
\hline Soil Sample & Number & $\begin{array}{c}\text { Moisture Content } \\
(\%)\end{array}$ & Density $\left(\mathrm{g} / \mathrm{cm}^{3}\right)$ & $\begin{array}{l}\text { Specific } \\
\text { Gravity }\end{array}$ & $\begin{array}{l}\text { Dry Density } \\
\left(/ \mathrm{cm}^{3}\right)\end{array}$ & Porosity \\
\hline \multirow{2}{*}{ Natural loess } & $\mathrm{Q}_{3}$ & 9.7 & 1.50 & 2.70 & 1.37 & 0.97 \\
\hline & $\mathrm{Q}_{2}$ & 15.0 & 1.78 & 2.69 & 1.55 & 0.74 \\
\hline \multirow{6}{*}{$\begin{array}{l}\text { Backfilled loess of } \\
\text { CSYZ }\end{array}$} & F-C-1 & 17.2 & 1.95 & 2.71 & 1.66 & 0.63 \\
\hline & F-C-2 & 18.4 & 1.77 & 2.71 & 1.49 & 0.81 \\
\hline & F-C -3 & 16.8 & 1.85 & 2.71 & 1.58 & 0.71 \\
\hline & F-C-4 & 17.1 & 1.84 & 2.71 & 1.57 & 0.72 \\
\hline & F-C-5 & 17.2 & 1.94 & 2.71 & 1.66 & 0.64 \\
\hline & F-C-6 & 16.5 & 1.87 & 2.71 & 1.61 & 0.69 \\
\hline \multirow{6}{*}{ Backfilled loess of SJG } & F-S-1 & 20.4 & 2.08 & 2.73 & 1.73 & 0.58 \\
\hline & F-S-2 & 20.1 & 1.91 & 2.73 & 1.59 & 0.72 \\
\hline & F-S-3 & 24.4 & 1.93 & 2.73 & 1.55 & 0.76 \\
\hline & F-S-4 & 22.2 & 1.89 & 2.73 & 1.55 & 0.77 \\
\hline & F-S-5 & 21.6 & 1.99 & 2.73 & 1.64 & 0.67 \\
\hline & F-S-6 & 19.1 & 1.82 & 2.73 & 1.53 & 0.79 \\
\hline Soil Sample & Number & Saturation (\%) & Liquid Limit & Plastic Limit & Plasticity Index & \\
\hline \multirow{2}{*}{ Natural loess } & $\mathrm{Q}_{3}$ & 26.87 & 17.8 & 27.6 & 9.8 & \\
\hline & $\mathrm{Q}_{2}$ & 54.68 & 17.1 & 28.0 & 10.9 & \\
\hline \multirow{6}{*}{$\begin{array}{c}\text { Backfilled loess of } \\
\text { CSYZ }\end{array}$} & F-C-1 & 74.13 & 18.7 & 28.0 & 9.3 & \\
\hline & F-C -2 & 61.35 & 17.3 & 30.3 & 13.0 & \\
\hline & F-C-3 & 64.04 & 18.0 & 27.8 & 9.8 & \\
\hline & F-C -4 & 63.95 & 18.4 & 28.2 & 9.8 & \\
\hline & F-C-5 & 73.15 & 17.4 & 25.8 & 8.4 & \\
\hline & F-C-6 & 64.96 & 16.9 & 25.3 & 8.4 & \\
\hline \multirow{6}{*}{ Backfilled loess of SJG } & F-S-1 & 95.98 & 17.6 & 26.0 & 8.4 & \\
\hline & F-S-2 & 76.57 & 16.4 & 24.8 & 8.4 & \\
\hline & F-S-3 & 87.69 & 17.5 & 26.0 & 8.5 & \\
\hline & F-S-4 & 79.21 & 17.6 & 26.1 & 8.5 & \\
\hline & F-S-5 & 88.25 & 19.1 & 25.4 & 6.3 & \\
\hline & F-S-6 & 66.30 & 19.5 & 25.8 & 6.3 & \\
\hline
\end{tabular}
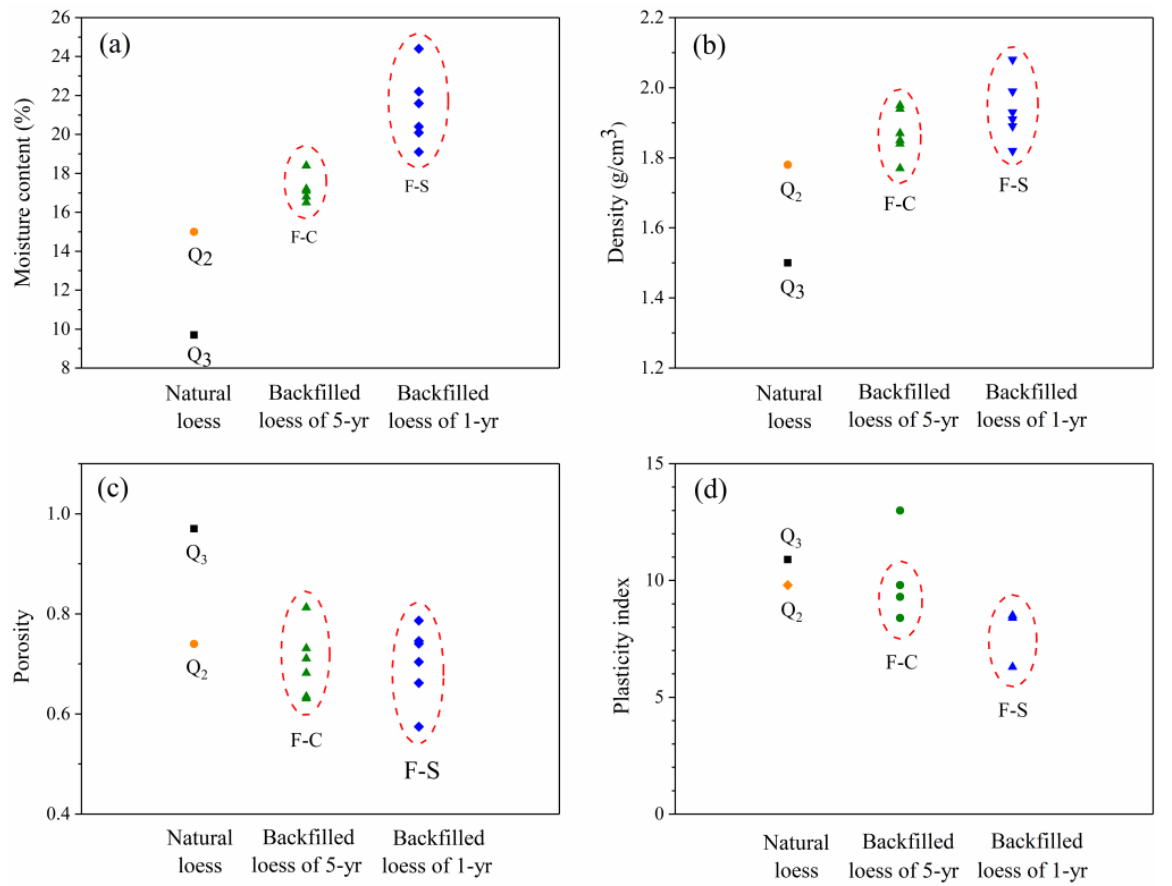

Figure 6. Comparison of basic physical properties: (a) moisture content, (b) density, (c) porosity, and (d) plasticity index.

On the contrary, the porosity of backfilled loess is significantly lower than that of natural loess (Figure 6c). The porosity ratio of $\mathrm{Q}_{3}$ and $\mathrm{Q}_{2}$ is 0.97 and 0.74 , respectively. The porosity ratio of F-C varies from $0.63-0.81$, and that of F-S ranges from 0.58 to 0.79 . The mean porosity of F-C increased 
compared with that of F-S. Similarly, the plasticity index of backfilled loess is also lower than that of natural loess from slopes (Figure 6d). The values of F-C samples are mainly distributed in the range of 8.4-9.8, while the values of F-S samples have an obvious decrease and are mainly distributed in the range of $6.3-8.5$.

\subsection{Grain Size Distribution}

Figure 7 shows the results of grain analysis tests. It can be seen that the grain size accumulation curves of 14 samples is smooth and continuous, with a granularity distribution ranging from $0.523 \mu \mathrm{m}$ to $111 \mu \mathrm{m}$. Among all curves, $\mathrm{Q}_{3}$ is located on the far left of the graph, $\mathrm{Q}_{2}$ and F-C are mostly concentrated in the middle part, and F-S is mostly distributed on the right. It can be seen from Table 2 that $Q_{3}$ has four maximums of characteristic grain size indices, $d_{60}, d_{50}, d_{30}$, and $d_{10}$. Overall, although there are no significant differences, the indices of SJG are slightly higher than those of CSYZ.

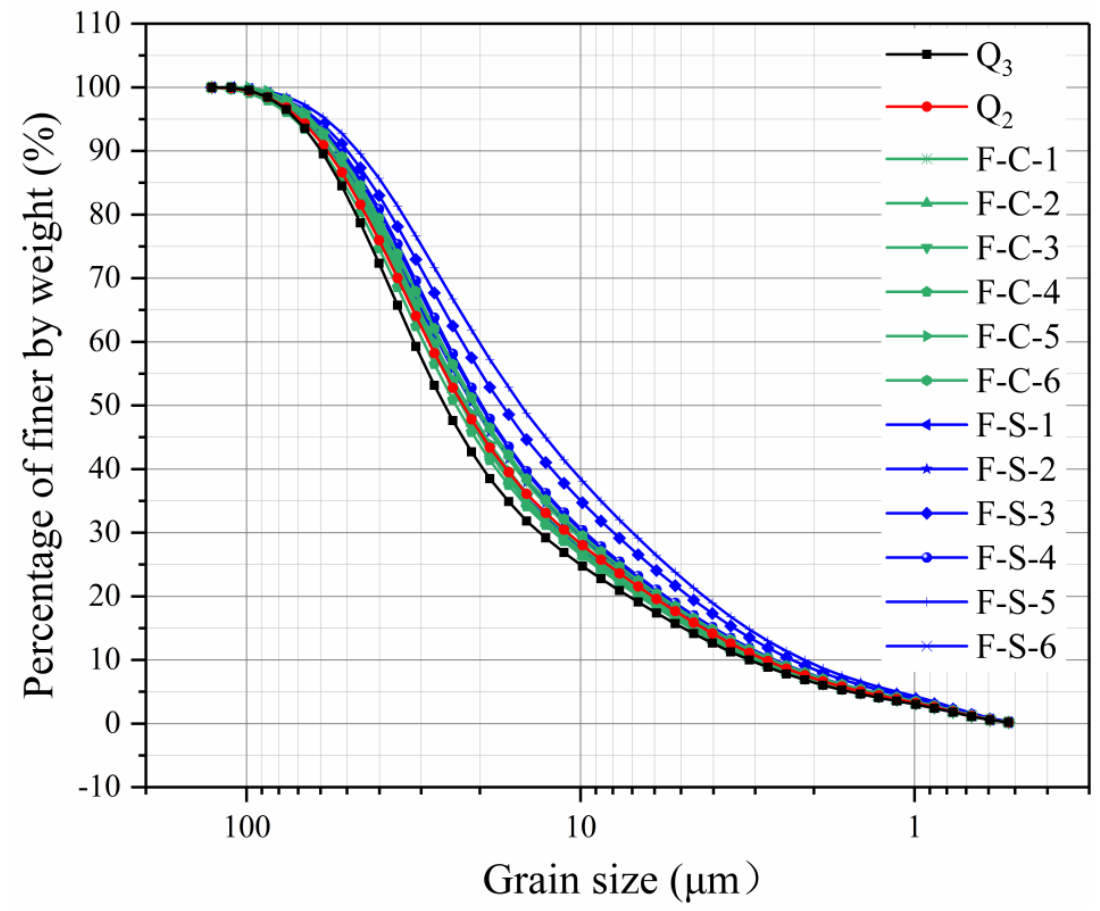

Figure 7. Grain size accumulation curves of 14 samples.

Table 2. Characteristic indices of granularity of 14 loess groups.

\begin{tabular}{|c|c|c|c|c|c|c|c|}
\hline Soil Sample & Number & $\begin{array}{l}d_{60} \\
\mu \mathrm{m}\end{array}$ & $\begin{array}{l}d_{50} \\
\mu \mathrm{m}\end{array}$ & $\begin{array}{l}d_{30} \\
\mu \mathrm{m}\end{array}$ & $\begin{array}{l}\mathrm{d}_{10} \\
\mu \mathrm{m}\end{array}$ & $\mathrm{C}_{\mathrm{u}}$ & $\mathrm{C}_{\mathrm{c}}$ \\
\hline \multirow{2}{*}{ Natural loess } & $\mathrm{Q}_{3}$ & 31.50 & 26.00 & 14.00 & 3.10 & 10.16 & 2.01 \\
\hline & $\mathrm{Q}_{2}$ & 28.00 & 23.00 & 11.00 & 2.90 & 9.66 & 1.49 \\
\hline \multirow{6}{*}{$\begin{array}{c}\text { Backfilled loess of } \\
\text { CSYZ }\end{array}$} & F-C-1 & 27.50 & 21.50 & 10.00 & 2.70 & 10.19 & 1.35 \\
\hline & F-C-2 & 23.00 & 18.00 & 8.00 & 2.30 & 10.00 & 1.21 \\
\hline & F-C-3 & 25.00 & 20.00 & 9.80 & 2.60 & 9.62 & 1.48 \\
\hline & F-C-4 & 20.00 & 16.00 & 7.00 & 2.10 & 9.52 & 1.17 \\
\hline & F-C-5 & 28.00 & 23.00 & 12.50 & 3.00 & 9.33 & 1.86 \\
\hline & F-C-6 & 26.00 & 21.00 & 11.00 & 2.80 & 9.29 & 1.66 \\
\hline \multirow{6}{*}{$\begin{array}{c}\text { Backfilled loess of } \\
\text { SJG }\end{array}$} & F-S-1 & 28.00 & 23.00 & 12.00 & 3.00 & 9.33 & 1.71 \\
\hline & F-S-2 & 28.00 & 23.00 & 12.00 & 3.00 & 9.33 & 1.71 \\
\hline & F-S-3 & 29.50 & 24.00 & 13.00 & 3.00 & 9.83 & 1.91 \\
\hline & F-S-4 & 26.00 & 20.00 & 10.00 & 2.70 & 9.63 & 1.42 \\
\hline & F-S-5 & 28.00 & 22.00 & 12.00 & 2.90 & 9.66 & 1.77 \\
\hline & F-S-6 & 27.00 & 21.00 & 10.00 & 2.70 & 10.00 & 1.37 \\
\hline
\end{tabular}

Note: $d_{10}, d_{30}, d_{50}, d_{60}$ are values corresponding to $10 \%, 30 \%, 50 \%$, and $60 \%$ finer by weight, respectively; $C_{u}$ is uniformity coefficient, $C_{\mathrm{u}}=\frac{d_{60}}{d_{10}}$; and $C_{\mathrm{c}}$ is curvature coefficient, $C_{\mathrm{c}}=\frac{d_{30}^{2}}{d_{10} \times d_{60}}$ 
In addition, the uniformity coefficient $\left(\mathrm{C}_{\mathrm{u}}\right)$ and curvature coefficient $\left(\mathrm{C}_{\mathrm{c}}\right)$ are two important indices for evaluating grain grading. In the tests, all soil samples satisfied $C_{u} \geq 5$ and $C_{c}=1-3$, which indicates well-graded particle sizes of these soils. Comparing the indices of natural and backfilled loess, the latter decreased, and the decrease of CSYZ is greater (Table 2).

\subsection{Direct Shear Tests}

The shear strength indices of the four types of samples were obtained through direct shear tests (Table 3 and Figure 8). The results indicate that the cohesion of $\mathrm{Q}_{3}, \mathrm{Q}_{2}, \mathrm{~F}-\mathrm{C}$, and F-S is $20.11 \mathrm{kPa}, 34.51$ $\mathrm{kPa}, 13.61 \mathrm{kPa}$, and $18.64 \mathrm{kPa}$ and the internal friction angle is $23.7^{\circ}, 28.8^{\circ}, 31.0^{\circ}$, and $33.8^{\circ}$, respectively. Compared with natural loess, the cohesion of backfilled loess decreased, and the decrease of F-C is much larger than that of F-S, the internal friction increased, and the increase of F-C is less than that of F-S.

Table 3. Indices of shear strength for $\mathrm{Q}_{3}, \mathrm{Q}_{2}, \mathrm{~F}-\mathrm{C}$, F-S samples.

\begin{tabular}{|c|c|c|c|c|c|}
\hline Soil Sample & Number & Normal Stress (kPa) & $\begin{array}{c}\text { Shear Strength } \\
(\mathbf{k P a})\end{array}$ & $\begin{array}{l}\text { Cohesion } \\
(\mathrm{kPa})\end{array}$ & $\begin{array}{c}\text { Internal Friction } \\
\text { Angle }\left({ }^{\circ}\right)\end{array}$ \\
\hline \multirow{5}{*}{ Natural loess } & \multirow{3}{*}{$\mathrm{Q}_{3}$} & 50 & 48.2 & \multirow{3}{*}{20.11} & \multirow{3}{*}{23.7} \\
\hline & & 100 & 63.9 & & \\
\hline & & 250 & 136.5 & & \\
\hline & \multirow{2}{*}{$\mathrm{Q}_{2}$} & 50 & 67.0 & \multirow{2}{*}{34.51} & \multirow{2}{*}{28.8} \\
\hline & & 250 & 172.9 & & \\
\hline \multirow{4}{*}{ Backfilled loess of CSYZ } & \multirow{4}{*}{ F-C-4 } & 50 & 40.2 & \multirow{4}{*}{13.61} & \multirow{4}{*}{31.0} \\
\hline & & 100 & 63.6 & & \\
\hline & & 150 & 121.4 & & \\
\hline & & 250 & 157.0 & & \\
\hline
\end{tabular}

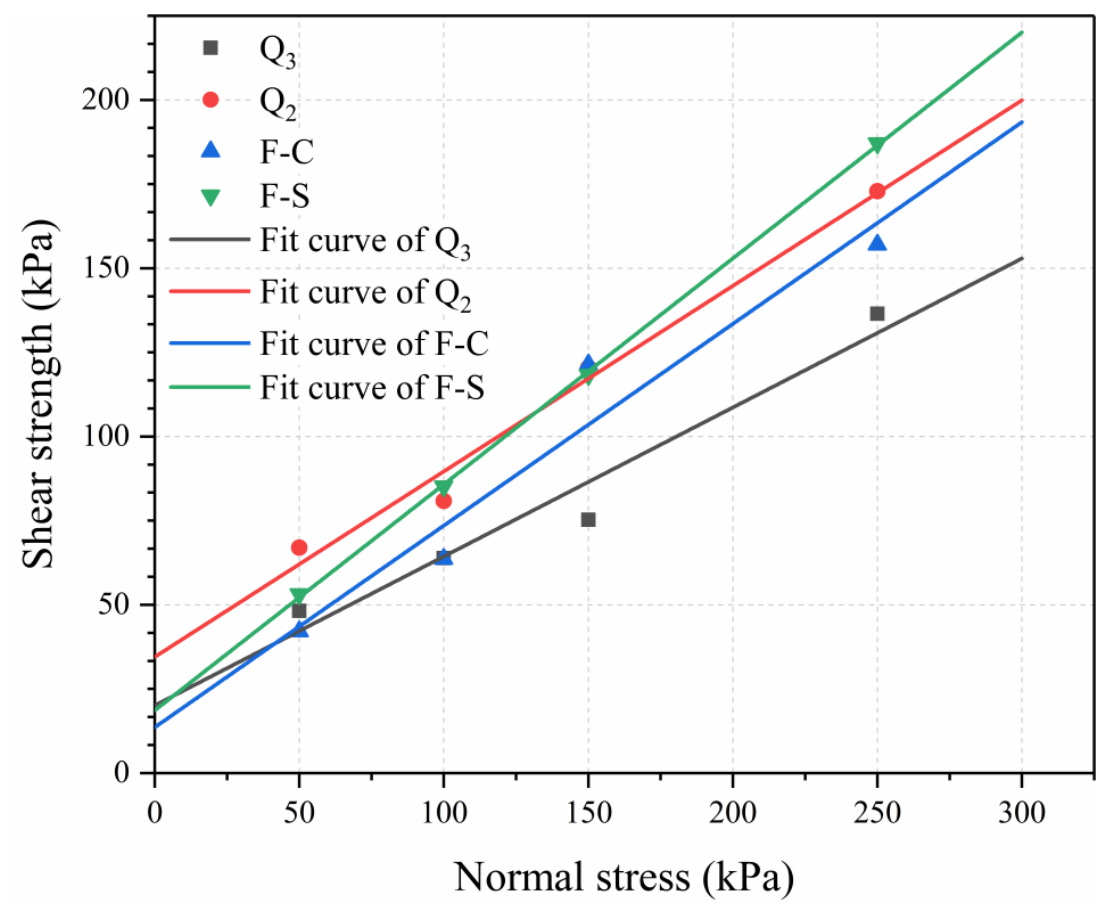

Figure 8. Normal stress-shear strength curves of $\mathrm{Q}_{3}, \mathrm{Q}_{2}, \mathrm{~F}-\mathrm{C}, \mathrm{F}-\mathrm{S}$ samples. 


\subsection{Compression Tests}

Using coefficients of compressibility and modulus of compressibility as criteria to evaluate the compressibility of soils, it can be found that loess of $Q_{3}, Q_{2}$, and F-S has an intermediate level of compressibility, and F-C is at a low level (Table 4). The porosity ratio of F-S is lower than that of $\mathrm{Q}_{3}$, but compressibility is greater (Figure 9), indicating that the compressibility of soil is related not only to the total pore volume, but also to the age and water content of the soil, the shape of soil particles, the strength of soil skeletons, and the pore distribution. Therefore, it is necessary to further study the microstructural characteristics of loess.

Table 4. Indices of compressibility for 14 loess groups.

\begin{tabular}{|c|c|c|c|c|c|c|c|c|c|}
\hline \multicolumn{2}{|c|}{ Number } & \multirow{2}{*}{$\begin{array}{c}\mathbf{Q}_{3} \\
0.16\end{array}$} & \multirow{2}{*}{$\begin{array}{c}\mathbf{Q}_{2} \\
0.12\end{array}$} & \multirow{2}{*}{$\begin{array}{c}\text { F-C-1 } \\
0.08\end{array}$} & \multirow{2}{*}{$\begin{array}{c}\text { F-C-2 } \\
0.07\end{array}$} & \multirow{2}{*}{$\begin{array}{c}\text { F-C-3 } \\
0.08\end{array}$} & \multirow{2}{*}{$\begin{array}{c}\text { F-C-4 } \\
0.07\end{array}$} & \multirow{2}{*}{$\begin{array}{c}\text { F-C-5 } \\
0.09\end{array}$} & \multirow{2}{*}{$\begin{array}{c}\text { F-C-6 } \\
0.05\end{array}$} \\
\hline$\alpha$ & $\mathrm{MPa}^{-1}$ & & & & & & & & \\
\hline $\mathrm{E}_{S}$ & $\mathrm{MPa}$ & 12.45 & 14.30 & 19.55 & 27.00 & 18.45 & 23.40 & 18.55 & 33.05 \\
\hline \multicolumn{2}{|c|}{ Number } & F-S-1 & F-S-2 & F-S-3 & F-S-4 & F-S-5 & F-S-6 & & \\
\hline$\alpha$ & $\mathrm{MPa}^{-1}$ & 0.14 & 0.19 & 0.38 & 0.22 & 0.17 & 0.22 & & \\
\hline $\mathrm{E}_{S}$ & $\mathrm{MPa}$ & 11.40 & 9.05 & 9.40 & 7.90 & 9.90 & 7.95 & & \\
\hline
\end{tabular}

Note: $\alpha$ is the coefficient of compressibility and $\mathrm{E}_{\mathrm{S}}$ is the modulus of compressibility.
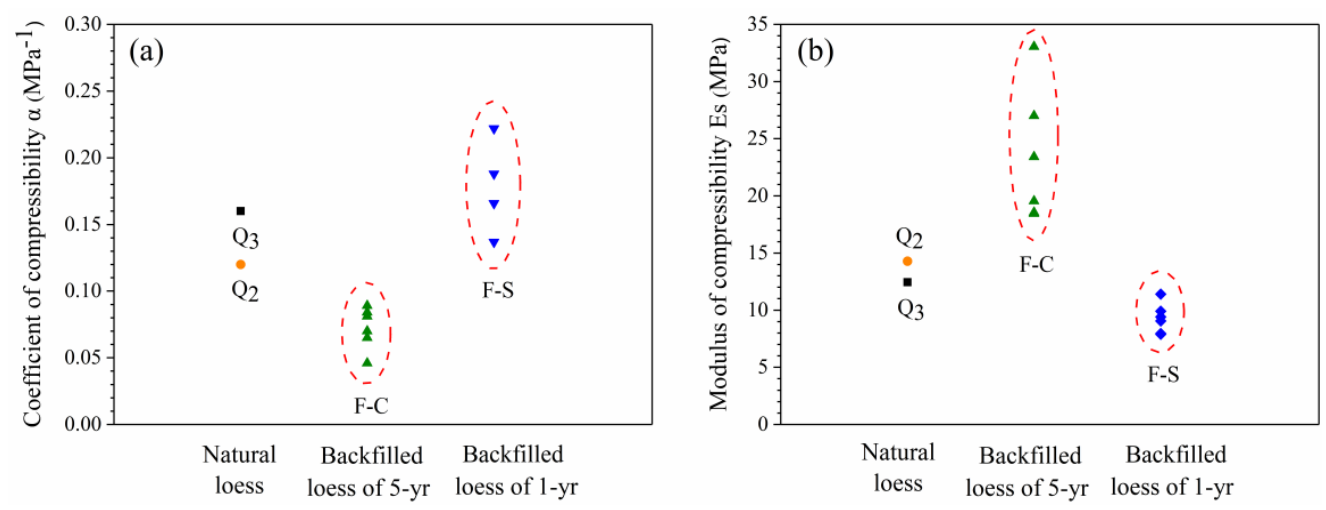

Figure 9. (a) Coefficient of compressibility, (b) modulus of compressibility.

\subsection{Scanning Electron Microscope Tests}

The SEM tests indicate that the microstructure of $\mathrm{Q}_{3}$ loess is loose, with clear grains and outlines (Figure 10a,b). The shape of the grains is granular, and surfaces presented with friable minerals. The particles mainly had point-to-point contact with each other. The intergranular pores are developed, in which scaffold pores are predominant, and the connectivity among pores is pretty good (Figure 10a,b). Compared to the structure of $Q_{3}$, the structure of $Q_{2}$ loess is much denser, and the particle outlines are blurred. The particle forms mainly include aggregates and clots, and surfaces are mainly cemented face-to-face. The pores of $\mathrm{Q}_{2}$ are reduced, and most are mosaic and intra-particle pores (Figure 10c, $\mathrm{d}$ ). The grain distribution of the F-C backfilled loess is more uniform, and its structure is denser than that of the $Q_{3}$ loess. The aggregated clay particles are mainly attached on the surfaces, showing that soil particles tended to be rounded when softened by water. The particles have both point-to-point and face-to-face contact patterns. F-C is dominated by mosaic pores and a small number of scaffold pores. It can be seen that some small particles filled in the large gaps (Figure 10e,f). The structure of the F-S backfilled loess is also dense, while the grain distribution is not uniform. Similarly, the aggregated clay particles are mainly attached on the surfaces, and the particles have both point-to-point and face-to-face contact patterns. There are more mosaic and intra-particle pores. High magnification shows that there is structural damage among the soil particles, and some flocculent particles caused by water softening filled into the pores (Figure 10g,h). 

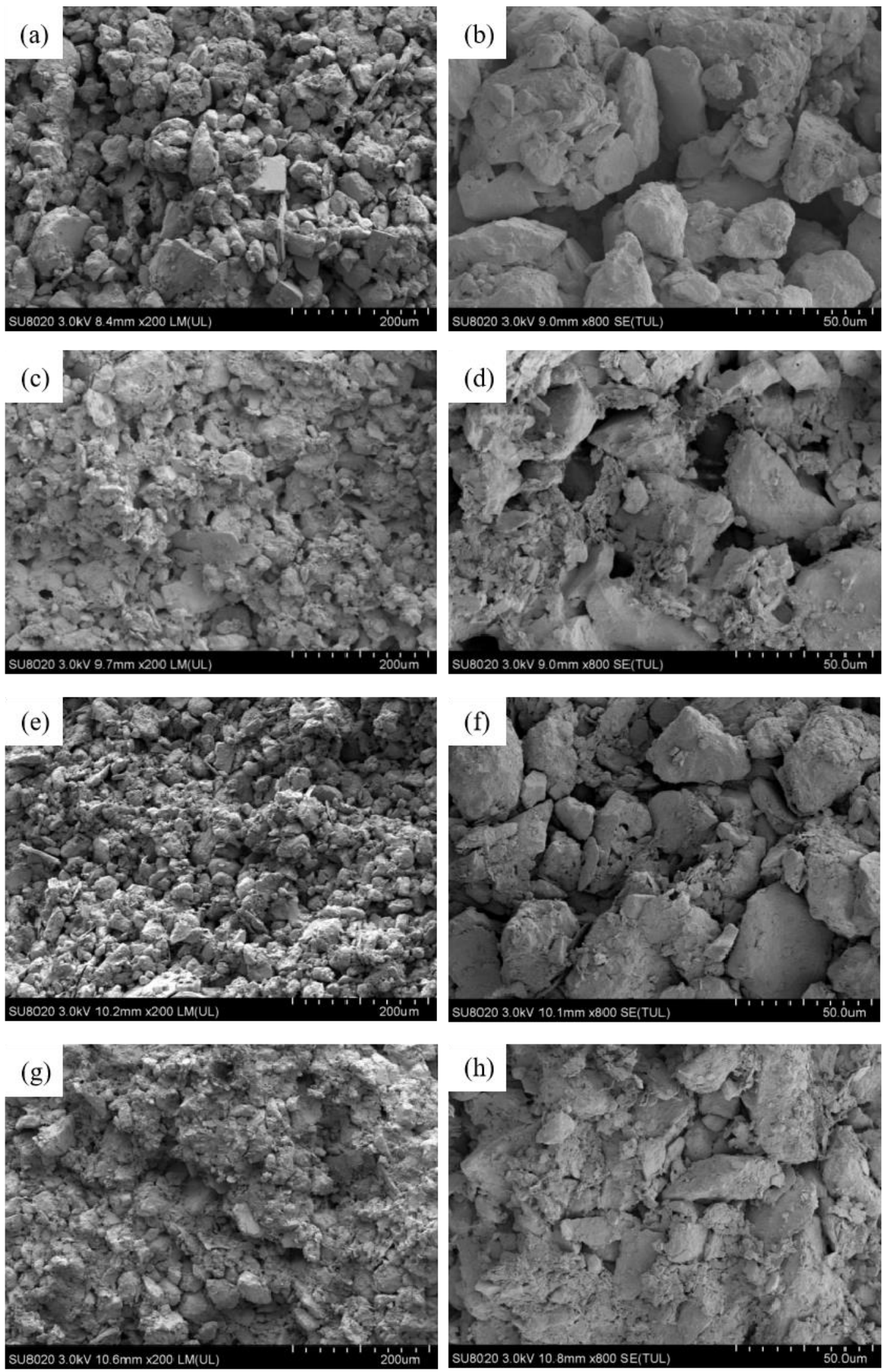

Figure 10. SEM images of $Q_{3}, Q_{2}, F-C$, and F-S samples: (a) $Q_{3}$ under 200 $\times$, (b) $Q_{3}$ under $800 \times$, (c) $Q_{2}$ under 200×, (d) $\mathrm{Q}_{2}$ under 800×, (e) F-C under 200x, (f) F-C under 800×, (g) F-S under 200x, and (h) F-S under $800 \times$. 


\subsection{Mercury Intrusion Porosimetry Tests}

Figure 11 shows the curves of cumulative intrusion vs. pore size, and the volume of cumulative intrusion represents the cumulative volume of the pore. It can be seen that the largest volume of mercury intrusion is $0.3041 \mathrm{~mL} / \mathrm{g}$ for the $\mathrm{Q}_{3}$ loess, followed by $0.2420 \mathrm{~mL} / \mathrm{g}$ for the $\mathrm{Q}_{2}$ loess, and $0.1883 \mathrm{~mL} / \mathrm{g}$ and $0.1785 \mathrm{~mL} / \mathrm{g}$ for F-C and F-S. The corresponding porosity ratio of the four groups is calculated as $0.77,0.61,0.48$, and 0.46 . It can be found that the porosity of the backfilled loess is significantly reduced, which is consistent with the SEM test results.

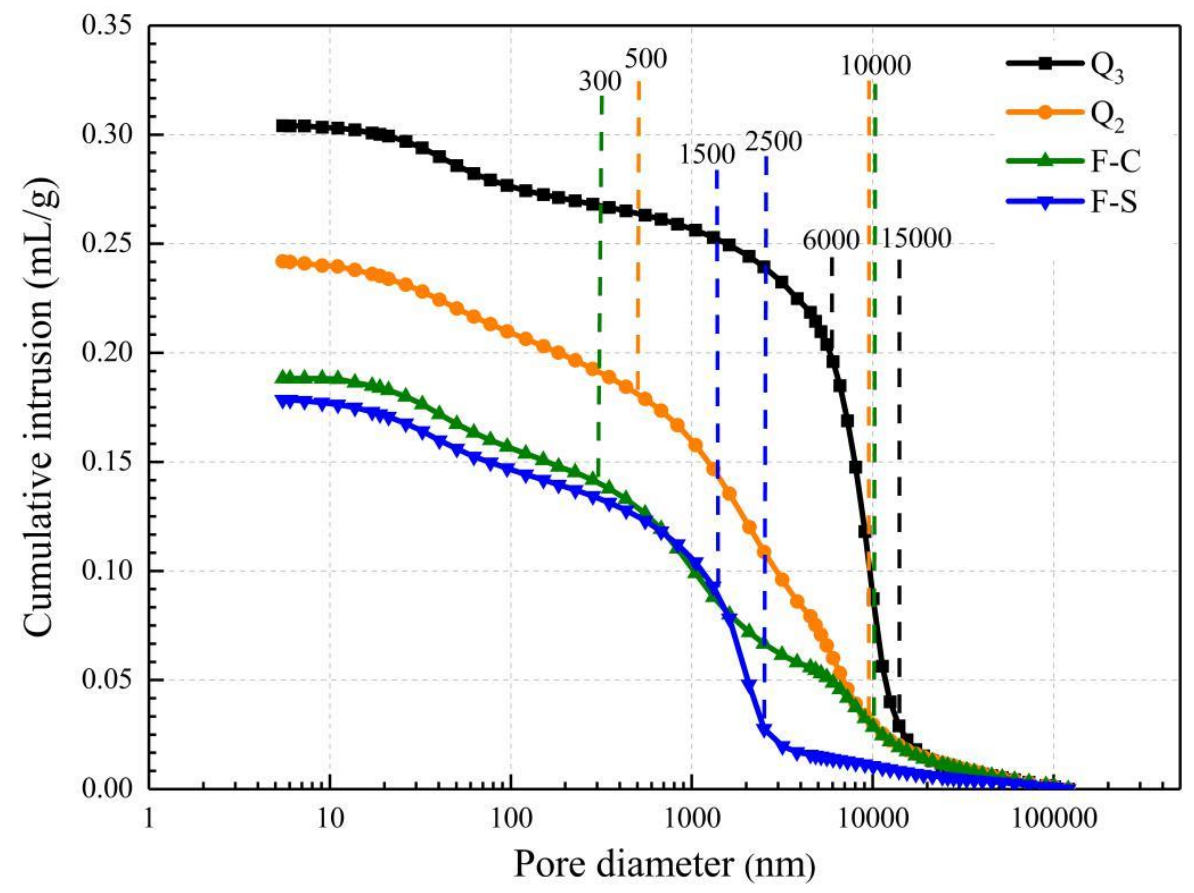

Figure 11. Cumulative intrusion vs. pore size of $\mathrm{Q}_{3}, \mathrm{Q}_{2}, \mathrm{~F}-\mathrm{C}$, and F-S samples.

Moreover, the slope of the cumulative intrusion vs. pore size curve of $\mathrm{Q}_{3}$ loess is abrupt in the range of pore diameters from 6000 to $15000 \mathrm{~nm}$, indicating that as the pore diameter decreased, the amount of mercury intrusion changed significantly. Therefore, it can be deduced that the pore diameter of sample $Q_{3}$ is mainly distributed in the range of $6000-15,000 \mathrm{~nm}$, and this range is called the dominant pore diameter. In the same way, the curve of F-S loess also has a stage of steep slope, and its dominant pore diameter ranges from 1500 to $2500 \mathrm{~nm}$. However, the curves of $\mathrm{Q}_{2}$ loess and F-C loess are relatively gentle, and the dominant pore diameter is distributed in the ranges of $500-10,000$ and 300-10,000 nm, respectively. The characteristics of the dominant pore diameter are not significant, and the pore distribution is relatively uniform. At the same time, it can be found that compared with natural loess, the range of dominant pore diameters for backfilled loess moves in the direction of the smaller pore size.

Figure 12 shows curves of pore size distribution (PSD) of four types of loess. Since PSD curves for Q3 and F-S have a significant peak, they are named single-peak curves [32,33]. The peak diameter of $\mathrm{Q}_{3}$ is $10,062 \mathrm{~nm}$, and F-S is $1613 \mathrm{~nm}$. However, for loess of $\mathrm{Q}_{2}$ and F-C, there are two peaks on the PSD curves, which are named double-peak curves. The two peak values of $Q_{2}$ are 1615 and $6582 \mathrm{~nm}$, and those of F-C are 832 and $8053 \mathrm{~nm}$. 


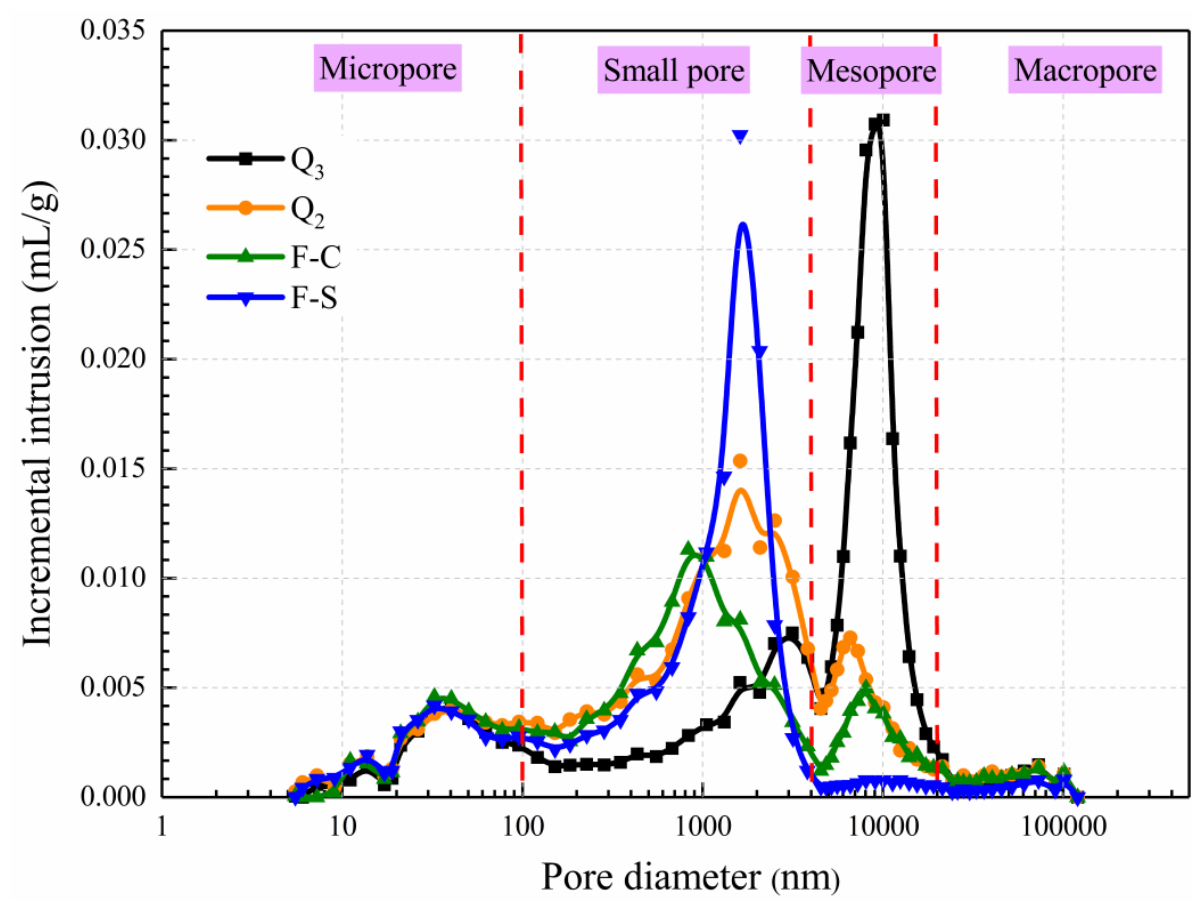

Figure 12. Pore size distribution curves of $\mathrm{Q}_{3}, \mathrm{Q}_{2}, \mathrm{~F}-\mathrm{C}$, and F-S samples.

\section{Discussion}

SJG gully is about $1.5 \mathrm{~km}$ away from CSYZ gully, and the main strata are basically similar. There is not much difference in the elevations at the sampling sites between CSYZ and SJG, which are $1170-1185 \mathrm{~m}$ and $1168-1172 \mathrm{~m}$. respectively. Hence, the assumption of this study is that the contribution of $Q_{2}$ and $Q_{3}$ loess in backfilled sites for CSYZ and SJG would be similar. A field survey showed that the major plant in SJG was alfalfa, and found that some crops are not growing well in the backfilled loess. Alfalfa is a plant with strong vitality in northern China that can adapt to a newly backfilled farmland environment well. Therefore, farmers always plant alfalfa on newly backfilled farmland to improve the soil. Based on the above, the effects of farming and backfilled time on soil properties were comparatively studied.

\subsection{Analysis of Physical-Mechanical Properties}

From Table 2 and Figure 6, the test results show that the moisture content and density of backfilled loess increased compared with natural loess. On the contrary, the porosity and plasticity indices decreased. With increased backfill time, almost all of the above-mentioned physical properties converged toward the natural loess. This reflects that backfilled soils tend to recover to their natural state when subjected to environmental processes such as wet/dry and seasonal cycles.

The analysis of grain size distribution (Figure 7) shows that there was breakage of a few large soil particles in the GLC process, and the mean grain size of backfilled farmland loess decreased (Table 2). Since the sampling depth of $0.5 \mathrm{~m}$ is within the influence range of plant cultivation [34-36], farming will affect the properties of soils. Some studies have shown the importance of soil functioning and soil-plant interactions [37-39]. For this study, under the influence of farm operations such as cultivation, irrigation, and digging, loess particle distribution tended to be homogenized.

Compared with natural loess, the cohesion of backfilled loess decreases, and the decrease of F-C is much larger than that of F-S, while the internal friction increases, and the increase of F-C is less than that of F-S. The reason may be that backfilled loess was disturbed in the GLC process, and the cementation and electrostatic attraction among soil particles were destroyed while the occlusal effects between particles were strengthened, so the cohesion decreased a little, and the internal friction angles increased a little. It should be noted that compared with F-C (with five years of farming), F-S (with one 
year of farming) has larger cohesion and internal friction as well, which indicates that with rainfall and irrigation, the water content gradually increased (Table 1), and the cohesion and internal friction angles gradually decreased under farming.

\subsection{Analysis of Microstructural Characteristics}

The SEM tests indicate that the grains of backfilled loess (F-C and F-S) are tightly compacted, and the distribution of grains and pores is much denser than that of natural loess $\left(Q_{2}\right.$ and $\left.Q_{3}\right)$, thus backfilled loess has a relatively higher internal friction angle than natural loess. However, the cement between the particles has been damaged by disturbance, and the backfilled loess has relatively lower cohesion than natural loess.

There are many studies on the classification of pores in loess at home and abroad [40-43], but there is still no unified conclusion. In this study, we divided pores into four groups according to the PSD characteristics (Figure 12): Macropores (pore diameter $>20 \mu \mathrm{m}$ ), mesopores $(4-20 \mu \mathrm{m}$ ), small pores $(0.1-4 \mu \mathrm{m})$, and micropores $(<0.1 \mu \mathrm{m})$. It can be seen from Figure 12 that the four types of loess have similar volume contents of macropores and micropores, but obvious differences in the distribution of mesopores and small pores. Calculating the percentages of the four groups of pores according to the ratio of certain pore volume to total pore volume (Table 5), it can be seen that the $\mathrm{Q}_{3}$ loess is mainly dominated by mesopores of $4000-20,000 \mathrm{~nm}$, accounting for $67.5 \%$, and the $\mathrm{Q}_{2}, \mathrm{~F}-\mathrm{C}$, and F-S loess have mainly small pores of $100-4000 \mathrm{~nm}$, accounting for $52.5 \%, 51.7 \%$, and $71.7 \%$, respectively. This indicates that some large and medium pores in the soil were destroyed and turned into small pores and micropores as a result of the engineering of Gully Land Consolidation.

Table 5. Volume percentages of four categories of pores for $\mathrm{Q}_{3}, \mathrm{Q}_{2}, \mathrm{~F}-\mathrm{C}$, and F-S samples.

\begin{tabular}{ccccc}
\hline \multirow{2}{*}{ Type of Loess } & \multicolumn{4}{c}{ Volume Percentages $\mathbf{( \% )}$} \\
\cline { 2 - 5 } & $\begin{array}{c}\text { Macropores } \\
(\mathbf{>} \mathbf{2 0} \boldsymbol{\mu m})\end{array}$ & $\begin{array}{c}\text { Mesopores } \\
(\mathbf{4}-\mathbf{2 0} \boldsymbol{\mu \mathbf { m } )}\end{array}$ & $\begin{array}{c}\text { Small Pores } \\
\mathbf{( 0 . 1 - 4} \boldsymbol{\mu m})\end{array}$ & $\begin{array}{c}\text { Micropores } \\
(<\mathbf{0 . 1} \boldsymbol{\mu m})\end{array}$ \\
\hline $\mathrm{Q}_{3}$ & 4.3 & 67.5 & 18.3 & 9.9 \\
$\mathrm{Q}_{2}$ & 6.1 & 26.6 & 52.5 & 14.8 \\
$\mathrm{~F}-\mathrm{C}$ & 6.7 & 22.8 & 51.7 & 19.9 \\
$\mathrm{~F}-\mathrm{S}$ & 3.4 & 5.5 & 71.7 & 19.5 \\
\hline
\end{tabular}

\subsection{Suggestion for Gully Land Consolidation}

GLC changes the macroscopic properties and microstructure of loess, especially the moisture content, density, and pore size distribution. Soil moisture is a key factor influencing soil nutrient movement and soil quality in the semiarid Loess Plateau [44-46]. Meanwhile, the surface loess of backfilled farmland undergoes mechanical action, resulting in increased density and pore ratio. However, dense soil is not conducive to the growth of plant roots. Field surveys showed that most crops do not grow well in backfilled loess in the first few years. Alfalfa, as a kind of plant with strong vitality in northern China, can adapt to this new land environment well. Therefore, farmers switched to planting alfalfa on backfilled farmland in subsequent years. Under the influence of farmers' operations such as cultivation, irrigation, and digging, characteristics of backfilled loess tend to resemble those of natural loess, which will become loose and fertile. Hence, this study suggests that newly constructed farmland may not be suitable for planting crops. Farmers can make the soil fertile by planting vigorous grasses or shrubs, like alfalfa and robinia pseudoacacia. At the same time, it is important to control the compactness of soil during construction.

\section{Conclusions}

Test results show that physical-mechanical properties and microstructural characteristics of backfilled loess of one-year and five-year farmland are significantly affected by Gully Land Consolidation. 
(1) Compared with natural loess, the moisture content, and density of backfilled loess increase. On the contrary, the pore ratio, plasticity index, and particle size index decrease. Additionally, with the development of filling time, the physical indices of backfilled loess tend to resemble those of natural loess, and the fluctuation amplitudes gradually decrease.

(2) The microstructure of soil samples observed by SEM tests indicates that natural loess has a certain skeleton strength with a relatively stable structure between the grains and pores. However, the distribution of particles and pores in backfilled loess (F-C, F-S) becomes denser, but the skeleton strength between the particles is destroyed, and the structure is more unstable. It was observed that the particles of backfilled loess are rounded with large pores filled with crushed fine particles, which results in weakness of the skeleton and cement strength among particles and pores and strengthening of the internal friction angle.

(3) By MIP tests and microscopic analysis, it can be concluded that some larger and medium pores in backfilled soils were destroyed and turned into smaller pores and micropores, and the cement strength between particles was damaged, which essentially affects the physical-mechanical properties of loess.

(4) Disturbance of backfilled loess leads to an obvious decrease of cohesion, and a slight increase in internal friction compared with natural loess. With increased backfilled time, the farming effect becomes prominent over time, the loess soil moisture content increases gradually, and both the cohesion and internal friction of the backfilled loess soil decrease to different degrees.

(5) Newly constructed farmland may not be suitable for planting crops in the first few years. Farmers can make the soil fertile by planting vigorous grasses or shrubs, like alfalfa and robinia pseudoacacia. At the same time, it is important to control the compactness of soil during construction.

Author Contributions: Conceptualization, S.Q. and S.G.; Data curation, L.M., B.Z., and S.G.; Formal analysis, L.M, S.Q., B.Z., S.G., and X.Y.; Funding acquisition, S.Q., S.G. and Q.H.; Investigation, L.M., S.Q., S.G., and Q.H.; Methodology, S.Q., S.G. and Q.H.; Project administration, S.Q., B.Z. and S.G.; Resources, S.Q.; Supervision, S.Q. and S.G.; Validation S.Q.; Writing-original draft, L.M.; Writing-review and editing, S.Q., S.G., Q.H., and X.Y. All authors have read and agreed to the published version of the manuscript.

Funding: This research was funded by the State Key Research Development Program of China under grant no. 2017YFD0800501, the Natural Science Foundation of China under grants nos. 41790442 and 41825018, and the Q.H.Strategic Priority Research Program of the Chinese Academy of Sciences under grant no. XDA23090402.

Acknowledgments: Special thanks to Zhang Bin at the China University of Geosciences, Beijing, and Yang Jijin at the Institute of Geology and Geophysics, Chinese Academy of Sciences, for their help with the experiments.

Conflicts of Interest: The authors declare no conflict of interest.

\section{References}

1. Liu, T.S. Loess and Environment; Science Press: Beijing, China, 1985; pp. 5-10.

2. Li, Y.H.; Du, G.M.; Liu, Y.S. Transforming the Loess Plateau of China. Front. Agric. Sci. Eng. 2016, 3, 181-185. [CrossRef]

3. Fu, B.J. Soil erosion and its control in the loess plateau of China. Soil Use Manag. 1989, 5, 76-82. [CrossRef]

4. Cai, Q.G. Soil erosion and management on the Loess Plateau. J. Geogr. Sci. 2001, 11, 53-70. [CrossRef]

5. Liu, T.S. Loess Plateau $\mathcal{E}$ Agricultural Origin $\mathcal{E}$ Soil and Water Conservation; Seismological Press: Beijing, China, 2004; pp. 1-15.

6. Su, Z.R.; Wang, J. Water conservation benefits' analysis of eight key national rehabilitation areas. Soil Water Conserv. China 1992, 3, 1-4.

7. Lü, Y.; Fu, B.; Feng, X.; Zeng, Y.; Liu, Y.; Chang, R.; Sun, G.; Wu, B. A policy-driven largescale ecological restoration: Quantifying ecosystem services changes in the Loess Plateau of China. PLoS ONE 2012, 7, e31782.

8. Chen, Y.P.; Zhang, Y. Sustainable Model of Rural Vitalization in Hilly and Gully Region on Loess Plateau. Bull. Chin. Acad. Sci. 2019, 34, 708-716. [CrossRef]

9. Xiao, J.F. Satellite evidence for significant biophysical consequences of the "Grain for Green" Program on the Loess Plateau in China. J. Geophys. Res. Biogeosci. 2014, 119, 2261-2275. [CrossRef] 
10. Li, S.; Yang, S.N.; Liu, X.F.; Liu, Y.X.; Shi, M. NDVI-based analysis on the influence of climate change and human activities on vegetation restoration in the Shaanxi-Gansu-Ningxia Region, Central China. Remote Sens. 2015, 7, 11163-11182. [CrossRef]

11. He, C.X. How to develop modern agriculture in Yan 'an on the basis of the Gully Reclamation Project. J. Yan'an Univ. (Soc. Sci.) 2013, 35, 3.

12. Zhou, H.L.; Wang, W.Z.; Hao, Z.L. Gully Land Consolidation Benefits the People, Rebuild a Good South in North Shaanxi. Available online: http://www.igsnrr.ac.cn/xwzx/zhxw/201211/t20121116_3684668.html (accessed on 16 December 2015).

13. He, C.X. The situation, characteristics and effect of the Gully Reclamation Project in Yan'an. J. Earth Environ. 2015, 6, 59-64.

14. Liu, Q.; Wang, Y.; Zhang, J.; Chen, Y. Filling gullies to create farmland on the Loess Plateau. Environ. Sci. Technol. 2013, 47, 7589-7590. [CrossRef] [PubMed]

15. Liu, Z.P.; Shao, M.A.; Wang, Y.Q. Large-scale spatial interpolation of soil pH across the Loess Plateau, China. Environ. Earth Sci. 2013, 69, 2731-2741. [CrossRef]

16. Zhang, X.B.; Jin, Z. Gully land consolidation project in Yan'an is inheritance and development of wrap land dam project on the Loess Plateau. J. Earth Environ. 2015, 6, 261-264.

17. Jin, Z. The creation of farmland by gully filling on the Loess Plateau: A double-edged sword. Environ. Sci. Technol. 2014, 48, 883-884. [CrossRef] [PubMed]

18. Wei, H.A.; Wang, J.Y. Assessment of land consolidation suitability in Loess Hilly-gully Region in Yan'an City. Areal Res. Dev. 2013, 3, 129-132.

19. Jin, Z.; Guo, L.; Wang, Y.; Yu, Y.; Lin, H.; Chen, Y.; Chu, G.; Zhang, J.; Zhang, N. Valley reshaping and damming induce water table rise and soil salinization on the Chinese loess plateau. Geoderma 2019, 339, 115-125. [CrossRef]

20. Liu, Y.S.; Li, Y.R. Engineering philosophy and design scheme of gully land consolidation in Loess Plateau. Trans. Chin. Soc. Agric. Eng. 2017, 33, 1-9. [CrossRef]

21. Gao, G.R. Study of the Microstructures and the Collapse Mechanism in Loess Soil from Lanzhou. J. Lanzhou Univ. 1979, 2, 123-134.

22. Gao, G.R. Microstructure of loess soil in china relative to geologic environment. Acta Geol. Sin. 1984, 58, 265.

23. Gao, G.R. The distribution and geotechnical properties of loess soils, lateritic soils and clayey soils in China. Eng. Geol. 1996, 42, 95-104. [CrossRef]

24. Lei, X.Y.; Wang, S. Size of loess pores in relation to collapsibility. Hydrogeol. Eng. Geol. 1987, 31, $15-18$.

25. Zhao, J.B.; Chen, Y. Study on porosity and collapsibility of loess. J. Eng. Geol. 1994, 2, 76-83.

26. Chen, Z.H.; Fang, X.W.; Zhu, Y.Q.; Qin, B.; Yao, Z.H. Research on meso-structures and their evolution laws of expansive soil and loess. Rock Soil Mech. 2009, 30, 1-11. [CrossRef]

27. Jiang, M.J.; Hu, H.J.; Peng, J.B.; Leroueil, S. Experimental study of two saturated natural soils and their saturated remolded soils under three consolidated undrained stress paths. Front. Archit. Civ. Eng. China 2011, 5, 225-238. [CrossRef]

28. Jiang, Z.K. Analysis of Stability and Slope Ratio Optimization of Excavated Slope of Gully Land Consolidation Project in the Loess Hilly Area: A Case Study of Nangou in Yan'an City. Master Thesis, Chang'an University, Xi'an, China, 2019.

29. Ministry of Water Resources of the People's Republic of China. Standard for Soil Test method GB/T 50123-1999; China Planning Press: Beijing, China, 1999.

30. Washburn, E.W. Note on a method of determining the distribution of pore sizes in a porous material. Proc. Natl. Acad. Sci. USA 1921, 7, 115-116. [CrossRef] [PubMed]

31. Li, T.L.; Fan, J.W.; Xi, Y.; Xie, X.; Hou, X.K. Analysis for effect of microstructure on SWCC of compacted loess. J. Eng. Geol. 2019, 27, 1019-1026. [CrossRef]

32. Ehlers, W.; Wendroth, O.; De Mol, F. Characterizing pore organization by soil physical parameters. In Soil Struct; CRC: Boca Raton, FL, USA, 1995; p. 257.

33. Gao, L.; Wang, B.; Li, S.; Wu, H.; Wu, X.; Liang, G.; Gong, D.; Zhang, X.; Cai, D. Degré, A. Soil wet aggregate distribution and pore size distribution under different tillage systems after 16 years in the Loess Plateau of China. CATENA 2019, 173, 38-47. [CrossRef]

34. Venkatesh, B.; Lakshman, N.; Purandara, B.K.; Reddy, V.B. Analysis of observed soil moisture patterns under different land covers in Western Ghats, India. J. Hydrol. 2011, 397, 281-294. [CrossRef] 
35. Jia, Y.H.; Shao, M.A. Dynamics of deep soil moisture in response to vegetational restoration on the Loess Plateau of China. J. Hydrol. 2014, 519, 523-531. [CrossRef]

36. Deng, L.; Yan, W.; Zhang, Y.; Shangguan, Z. Severe depletion of soil moisture following land-use changes for ecological restoration: Evidence from northern China. For. Ecol. Manag. 2016, 366, 1-10. [CrossRef]

37. Frouz, J.; Livečková, M.; Albrechtová, J.; Chroňáková, A.; Cajthaml, T.; Pižl, V.; Háněl, L.; Starý, J.; Baldrian, P.; Lhotáková, Z.; et al. Is the effect of trees on soil properties mediated by soil fauna? A case study from post-mining sites. Ecol. Manag. 2013, 309, 87-95. [CrossRef]

38. Kravchenko, A.N.; Guber, A.K. Soil pores and their contributions to soil carbon processes. Geoderma 2016, 287, 31-39. [CrossRef]

39. Wang, H.; Yue, C.; Mao, Q.; Zhao, J.; Ciais, P.; Li, W.; Yu, Q.; Mu, X. Vegetation and species impacts on soil organic carbon sequestration following ecological restoration over the Loess Plateau, China. Geoderma 2020, 371, 114389. [CrossRef]

40. Lei, X.Y. Pore classification and collapsibility of loess in China. Sci. China 1987, 12, 1309-1318.

41. Osipov, V.I.; Sokolov, V.N. Factors and mechanism of loess collapsibility. In Genesis and Properties of Collapsible Soils; Derbyshire, E., Ed.; Proc. Workshop: Loughborough, UK, 1994; pp. 49-64.

42. Yang, Y.L. Study on collapsible mechanism of loess. Sci. China 1988, 7, 756-766.

43. Wei, Y.N.; Fan, W.; Yu, B.; Deng, L.S.; Wei, T.T. Characterization and evolution of three-dimensional microstructure of Malan loess. CATENA 2020, 192, 104585. [CrossRef]

44. Zhou, J.Y.; Gu, B.J.; Schlesinger, W.H.; Ju, X.T. Significant accumulation of nitrate in Chinese semi-humid croplands. Sci. Rep. UK 2016, 6, 25088. [CrossRef] [PubMed]

45. Song, X.L.; Gao, X.D.; Dyck, M.; Zhang, W.; Wu, P.T.; Yao, J.; Zhao, X.N. Soil water and root distribution of apple tree (Malus pumila mill) stands in relation to stand age and rainwater collection and infiltration system (RWCI) in a hilly region of the Loess Plateau, China. Catena 2018, 170, 324-334. [CrossRef]

46. Liu, Z.; Ma, P.; Zhai, B.; Zhou, J. Soil moisture decline and residual nitrate accumulation after converting cropland to apple orchard in a semiarid region: Evidence from the Loess Plateau. Catena 2019, 181, 104080. [CrossRef]

(C) 2020 by the authors. Licensee MDPI, Basel, Switzerland. This article is an open access article distributed under the terms and conditions of the Creative Commons Attribution (CC BY) license (http://creativecommons.org/licenses/by/4.0/). 